\title{
Am I A Leader? Female Students Leadership Identity Development
}

\author{
Brenda L. McKenzie \\ Senior Lecturer \\ Vanderbilt University
}

\begin{abstract}
This grounded theory study aimed to understand the process of leadership identity development experienced by traditional-aged female undergraduate college students. The findings led to a model for leadership identity development consisting of four phases. Students' leadership identity development progressed from views of leadership as external to self to positional leaders to incorporation of self-as-leader whether in a position or not. The final phase reflected a shift to leading for social change. In the early phases of the model, the female students in this study saw gender as irrelevant to them as leaders even though they recognized societal views of female leaders as weaker or less capable. In later phases they understood how being female mattered, and by Phase 4 they recognized a need to take a stand on societal issues related to gender and race.
\end{abstract}

\section{Introduction}

Women are underrepresented in positions of leadership in the workforce: only $27 \%$ of chief executive officers are women, compared with $72 \%$ of administrative leaders in fields such as human resources and 64\% of educational administration executives (Bureau of Labor Statistics, 2013). The percentage of women in executive positions is discouraging given the fact that many colleges and universities identify developing students into citizen leaders as a priority reflected in their mission statements. A tool utilized by many institutions to fulfill this mission is the creation of leadership development programs that "offer a variety of elements or activities designed for the purpose of enhancing student leadership development and learning" (Eich, 2008, p. 177). Eich (2008) found that, among other outcomes, high-quality leadership programs affect students' ability to broaden their leadership thinking, gain self-efficacy, and learn more about themselves; as such, these initiatives serve a valuable purpose in educating the next generation of leaders.

Research on college students and leadership has focused on specific models of leadership (e.g., Komives, Lucas, \& McMahon, 2013; Komives, Wagner, \& Associates, 2009; Kouzes \& Posner, 2008; Shankman \& Allen, 2008); leadership styles, behaviors, or approaches (Kezar \& Moriarty, 2000; Posner, 2009; Thompson, 2006); and the impact of specific leadership development initiatives or experiences (Cress, Astin, Zimmerman-Oster, \& Burkhardt, 2001; DiPaulo, 2008; Shertzer \& Schuh, 2004). The industrial model of leadership as position and leadership as individual were found to be dominant views held by students (Shertzer \& Schuh, 2004). Research has also indicated a perception that leaders possess particular qualities or skills (Posner, 2009; Shertzer \& Schuh, 2004). These studies provide insights into how students perceive leadership and identify the "best" leadership behaviors yet they do not help to understand how perceived traits impact students' leadership identity development. Additionally, 
few of these leadership studies focused specifically on female college students (for exceptions see Whitt, 1994, Haber, 2011, and Harber-Curran, 2013).

Broad based leadership research has examined leadership by gender (Eagly \& Carli, 2007; Gage, Mumma, \& Fritz, 2004), feminine and masculine characteristics of leadership (Eagly \& Carli, 2007; Pittinsky, Bacon, \& Welle, 2007; Valian, 1998), and perceptions of women's ability to lead (Rhode \& Kellerman, 2007). Yet most research on college students has studied either mixed-gender groups or male students exclusively (Arminio et al., 2000; DiPaolo, 2008; Harper \& Quaye, 2007). Furthermore, researchers have typically addressed leadership development from a traditional view: white, male, positional leadership. Studies have been conducted with women in business settings, focusing on specific skills (self-reported) or on others' perceptions of women as leaders (Roy, Weibust, \& Miller, 2009; Valian, 1998) but not on the process of leadership identity development. Other studies have shown that women's leadership styles are related to more contemporary leadership approaches, such as relational, collaborative, and social responsibility (Eagly \& Carli, 2007; Helgesen, 1990).

Because higher education institutions aim to develop students as leaders, it is necessary that institutions assist female students to understand what leadership challenges they may face after graduation. Instilling a sense of self-efficacy and helping female students identify as leaders while still in college could motivate them to seek leadership roles in the workplace and in society at large, leading to changes both in perceptions of the capability of female leaders as well as workplace demographics.

A few significant studies conducted specifically on women or girls do provide insights on female college student leadership development: Hoyt and Kennedy (2008) highlighted adolescence as a time when girls' self-identity is formed by societal constructs which often results in the silencing of the girls' voices. Additionally, seeing diverse female leaders as role models has been shown to contribute to female students' leadership development (Hoyt \& Kennedy, 2008; Whitt, 1994). Several other themes have emerged from studies focused specifically on female college students: these themes include the importance of relationships and perceptions about gender (Haber, 2011; Haber-Curran, 2013). These results resembled research findings from studies of women in the workforce, particularly balancing task and relationship behaviors and perceptions regarding gender roles and leadership. These findings provide useful information on the types of experiences that enhance female students' success as leaders, but are still disconnected from leadership identity development in female students.

Given what is understood about the constructs of identity development and college student leadership development, the question of what is known about leadership identity development remains. The limited research on leadership identity development has focused on adults, addressed leadership skill development and task expertise in relation to identity, and viewed leadership and leader development through the lens of self-concept or identity (Day \& Harrison, 2007; Lord \& Hall, 2005). One instrumental grounded theory study, conducted by Komives, Owen, Longerbeam, Mainella, and Osteen (2005) resulted in a six-stage leadership identity development (LID) model. Komives et al. concluded that the students moved from a leadercentric view of leadership to one in which leadership was viewed as a relational process. Findings from this study by Komives et al. (2005) connected to aspects of students' psychosocial 
development and focused on establishing healthy relationships and a confident sense of self. Since the initial study, additional LID research has focused on first-year students (Shehane, Sturkvant, Moore, \& Dooley, 2012), the role of high school experiences (Komives \& Johnson, 2009), students involved in fraternities and sororities (Lawhead, 2013), and on early- to midcareer professional women (Gonda, 2007). While these areas are important, there continues to be a lack of research regarding the role of gender in leadership identity development.

\section{Purpose of Study}

The purpose of this grounded theory study was to understand the process by which traditional-aged female undergraduate college students experience the development of a leadership identity. Leadership identity development is defined as the developmental processes or stages experienced by individuals which lead to self-conceptualization as a leader. Given that women and men tend to view their efficacy of leadership differently (Boatwright \& Egidio, 2003), understanding how the leadership identity development process differs for female undergraduate students is necessary. Gender-specific studies are needed in order to design effective initiatives, provide appropriate support for students, and to address the way students understand socially-constructed views of both leadership and gender. Providing opportunities for female students to develop, to become accustomed with societal views of female leadership, and to self-identify as leaders will prepare students for their experiences post-graduation.

\section{Methods}

This grounded theory study aimed to create a leadership identity development model for female college students, utilizing a constructivist grounded theory method, which is defined as a set of "systematic, yet flexible guidelines for collecting and analyzing qualitative data to construct theories 'grounded' in the data themselves" (Charmaz, 2006, p. 2). In order to mutually construct an initial understanding of an emerging model of leadership identity development, I worked with the participants to make sense of their insights and leadership experiences. This was accomplished through a series of individual interviews and a focus group.

Participants. The 20 students in this study were traditional-aged (defined as students between the ages of 18 and 22), female, undergraduate student leaders who came from a variety of backgrounds and experiences. The students were from a large, public research university in the Midwest. The students in this study had previously participated in leadership roles that included student leader staff (i.e. resident assistant, orientation leader), student athlete, student employee, or volunteer for mentoring programs as well as more traditional elected student organization officer positions. Of the 20 participants, three were sophomores, five juniors, and 12 seniors. There were four African Americans, one Latinx, and 15 Caucasian students.

Potential participants were identified through recommendations from student organization advisors and student employee supervisors. Identified students were contacted via email, outlining the study and inviting them to participate. Interested students were asked to complete a demographic questionnaire which served as a way of gauging potential participants' background as well as leadership experiences and level of engagement with student activities. 
Data Collection. Semi-structured individual interviews, lasting 60- to 90-minutes, were conducted with the 20 students who volunteered to participate in the study. The purpose of the interviews was to (a) discover students' individual leadership experiences and the individuals or experiences that influenced them and (b) understand each person's leadership identity development process as a way to understand and "portray" what this experience meant. All interviews were audio-taped and transcribed, and a pseudonym was assigned to each student.

Each student was also invited to participate in a focus group for group exploration and clarification of emerging categories. The focus group allowed for the co-construction of meaning from my initial data analysis, making connections among the participants' experiences and helping further shape the emerging categories.

Data Analysis. Initially, line-by-line coding was conducted in order to define each line of data which ensured that I was analyzing what the students stated rather than imposing my views on the data. A focused coding process followed to develop an initial set of categories that were either consistent across a majority of interviews or which needed clarification. The emerging themes developed through my focused coding process led to theoretical coding identifying "possible relationships between categories [you] have developed" (Charmaz, 2014, p. 150). As I integrated and further synthesized these codes, the leadership identity development model emerged.

\section{Results}

An analysis of the data produced five themes: influences, meaningful involvement, expanding views of leadership, changing views of self as leader, and reflective learning. These themes formed the foundation for a four-phase process of leadership identity development described below (see Figure 1). Progression from one phase to the next was often marked by a series of transitional experiences. Although this process is described in a linear fashion, the students did not move through the model in a straight line. The lines between the phases were fluid; students moved between phases, depending on their experiences and the successes or challenges they faced.

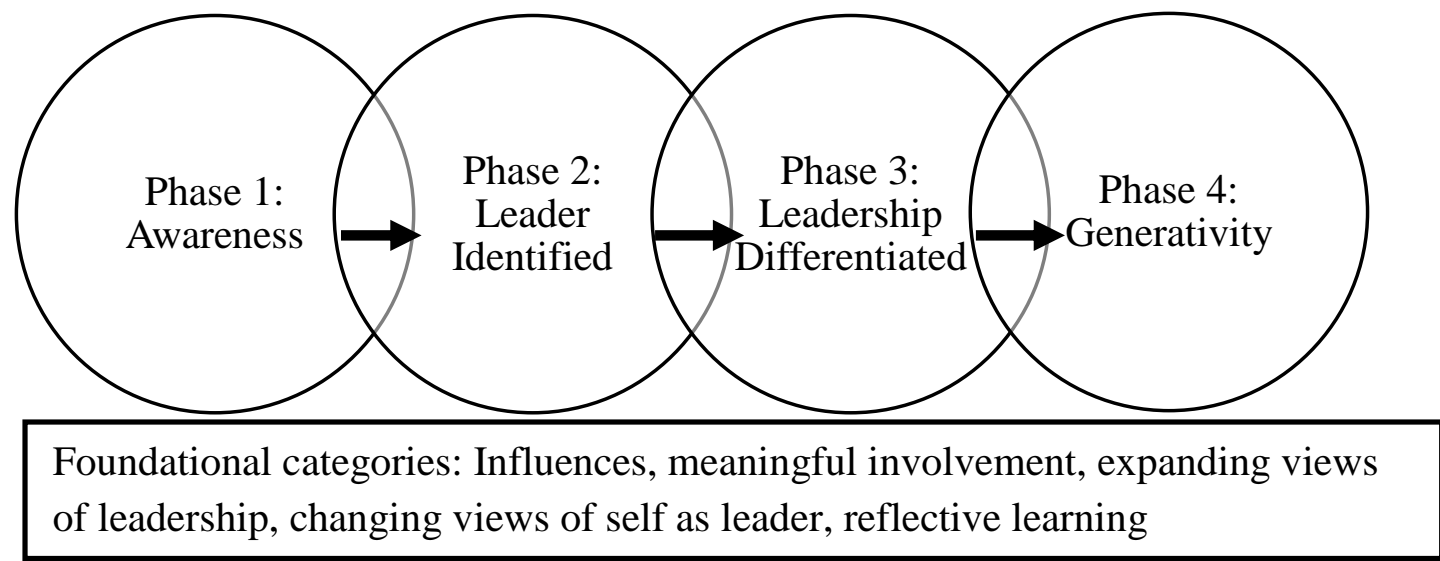

Figure 1: Leadership identity development model. 
Phase 1: Awareness and Exploration. Phase 1: Awareness and Exploration manifested in the belief of students that leadership existed externally to them, in others not in themselves. The students at this phase were provided with responsibilities and leadership opportunities, typically by adults, without seeing themselves as leaders or seeking out these opportunities on their own. Participants defined involvement as having fun, experiencing a sense of belonging, and exploring new opportunities as shown in the following data excerpts: "It was a lot of fun" (Wendy); "I just felt a sense of pride and belonging in band" (Cassie); "I just try new things" (Bridget). Students' did not self-identify as leaders or even consider that they could aspire to leadership. Students simply wanted to be a part of a group of people with whom they could connect and have fun. As students became more involved in activities, they understood what it meant to be a leader yet continued to be uncomfortable applying this label to themselves. Major aspects of the students' experiences in Phase 1 included exploring options and finding their comfort zones, not seeing themselves as leaders.

Expanding views of leadership. In Phase 1 students identified leaders as public figures, such as presidents or celebrities. Individuals who possessed necessary qualities, such as charisma, assertiveness, or extroversion, were leaders to be admired or respected; but few students in this phase aspired to be like these people. In addition to public figures, students looked up to people in their specific sphere of influence as potential leaders. These included peers, captains of their sports team, or teachers who exhibited behaviors that students respected. In Phase 1 students were unable to connect the concept of leadership in others with their own abilities. Cassie, for example, perceived herself to be the antithesis of a leader: "I always thought a leader was someone that was extroverted, that took charge, that people looked up to; and I just thought I was the opposite of that. Just someone who was just there." For students in this phase, leadership was directed externally, placed on others like a mantle that the students could not wear themselves at this point in their development.

Changing views of self as leader. Stemming from the unconscious influence of societal perceptions of leaders, changing views of self as leader were characterized by a lack of self-confidence. Naomi stated that she didn't "stand out" and questioned how she could be a leader. Students who struggled with self-confidence took longer to move into later developmental phases of leadership identity; some were still developing their confidence even as they concluded their college years and thus remained in this early phase of leadership identity development.

Students' views of leadership in Phase 1 may also have been influenced by societal views of female leadership. Naomi stated, "I would say that sometimes women aren't looked to as natural leaders, that sometimes it's a man's job." The students expressed an awareness of females needing to behave in certain approved ways and an understanding of the expectations placed on female leaders. Other students acknowledged that they saw males in more powerful positions in society. Rhonda spoke about the negative perception of women labeled as leaders: "I think there's a negative view sometimes of women as leaders, saying, 'Oh, they're too emotional, they can't do it." The students had not considered gender as a part of their own identity, thus preventing their application of what they saw or heard about female leaders to 
themselves. These societal perceptions of leaders may have unconsciously influenced the students' ability to consider that they could be leaders.

Transition from Phase 1 to Phase 2. Early in Phase 1: Awareness and Exploration students were unable to acknowledge that they were capable of being leaders. As the students gained more experiences and were encouraged to step into leadership roles, they understood what leadership might mean to them. The more these students heard people call them leaders, the more they internalized the concept and explored who they were as leaders. The movement from a view of leaders as others in Phase 1 to acknowledgment that leadership was a possible aspect of their own identities marked the transition by these students to Phase 2: Leader Identified. This transition often occurred in college when a student was first elected to a leadership position.

Phase 2: Leader Identified. As students in this study transitioned to Phase 2: Leader Identified, they acknowledged their capability to be leaders and began to identify themselves as such. Mirroring Komives et al.'s (2005) definition, the expression leader identified meant that leaders perform leadership and are responsible for group outcomes. For most students the transition to Phase 2 occurred during the first two to three years of college.

Expanding views of leadership. Early in Phase 2 students had difficulty clearly identifying what being a leader meant to them. Because of this lack of clarity, students had difficulty fully incorporating the role of leader into their identities. Students observed others to learn what leadership could mean and to identify leadership traits in others that they did/did not want to emulate. Faith stated, "I think a lot of it was just watching other people that were a couple years ahead of me in school and seeing what they were doing."

As students were elected to their first positional leadership roles, they typically believed that a leader maintained control, told others what to do, had authority over others, and took charge as illustrated by the following data excerpts: "need to be commanding and know how to hold somebody's attention and to give directions" (Gretchen); "take charge and just do things" (Joan).

Stepping up. In addition to views of leadership as control, a number of students early in Phase 2 exhibited a strong belief that leadership was about stepping up and doing what was needed. For some students, the concept of stepping up meant completing work and attending to details. Others equated stepping up with fulfilling obligations to the group. For still others, it meant taking the initiative to do what others were unwilling to do. The various ways of viewing stepping up is illustrated by these data excerpts: "I just see myself as any place I can help out, I want to help" (Wendy); "I just thought about it as me doing what needed to be done" (Holly). These views about stepping up reflected the students' varying levels of self-confidence. Those students who were more confident in their abilities were the ones who took the initiative and asked for responsibilities. Those less confident were more likely to feel a sense of obligation and to perceive that they were just doing what needed to be done or 
that they knew the "right" way to accomplish a task.

Perception of female leaders. During Phase 2, students continued to express traditional, socially-constructed views of female leaders. They perceived female leaders as emotional or leading by emotion. Students struggled to reconcile the way female leaders were viewed in society with their own views of self-as-leader. To the students a caring, emotional leader was concerned with the welfare of others and able to empathize with others; they rejected women leaders as "emotional messes" as illustrated by Leila's view of women leaders as "coming from a place of empathy and understanding." Participants dismissed the idea that women could not be leaders because women are overtly emotional, yet were also quick to use the same reasoning to defend male leaders who displayed characteristics traditionally associated with women as shown by the following examples: "Not to say that a man leader won't do that as well" (Leigh); "Not all guys are that way [overpowering and inconsiderate]" (Melissa). These qualifying, rationalizing statements showed that in Phase 2 the students had either accepted socially assigned gender roles or explored what it meant to be female and did not yet want be "different" from males.

Changing views of self as leader. A notable progression took place for students during Phase 2: Leader Identified as they passed from resistance of self as leader to exploration of various approaches to leadership and ultimately arrival at a place of confidence with their handling of leadership roles. Much of Phase 2 involved students' exploration, trying out different roles, styles, and approaches to find what worked for them and further developing selected characteristics before incorporating them into their identity.

Positional authority. In Phase 2 students took two approaches to leadership: at first associating leadership with authority or elected position and later as a more collaborative process. Identifying self as leader initially occurred for these students when they were elected to a position in college. Election by their peers also lent credibility to leadership. Throughout this phase students believed that leadership is earned. Wendy stated, "I view leadership as a position that is earned ... a as a trusted position. You've gotten to where you are because people trust in you, and you have built a rapport or credibility with people." The students' leadership identity was affirmed by others' views of them, not the way they saw themselves.

Collaborative leader. The second approach to leadership students experienced in Phase 2 involved increased collaboration. Students saw the value of working with others as opposed to directing them. As the shift occurred, the students broadened their perspectives, learning to work with different people as illustrated by Wendy, "I know how to approach different situations, talk to different people." Students realized that control was ineffective and that understanding led to better leadership. This shift was often facilitated by acquisition of a different perspective from an adult, exposure to new things, or the realization that others had demands on them as well. 
Having a voice. As students gained experiences, adjusted their perceptions of leadership, and were exposed to varying viewpoints, they became increasingly aware of the potential impact of gender on how they were perceived. The students also perceived variations in the way women led and saw value in the collaborative approach taken by their female peers, yet the students had not internalized the role of gender into who they were as individuals and who they were as leaders. Associated with the students' struggle to connect their gender identity to leadership was the concept of having a voice. Several students shared examples of times when they felt they had no voice, particularly when in the presence of others they perceived as strong leaders (typically males). In these situations the students deferred to others, remaining silent. They believed that their voices were useful only when they had the power and authority of a title to back them up. Students gained self-confidence but had still not come to see the value of their voices no matter what their role.

Transition from Phase 2 to Phase 3. As students moved through Phase 2: Leader Identified and transitioned to Phase 3: Leadership Differentiated, they moved away from the idea of needing to control every aspect and became more open to others' views and ideas, recognizing the value of including everyone in a process. Students also viewed leadership as more than a label and understood their responsibility to develop leadership in others. The students had developed new skills, moved up in the ranks of their organizations, and realized that they could help others develop as leaders. These transitional experiences reflected movement into Phase 3 , incorporating an advanced view of leadership and a stronger sense of self-confidence into their identities as leaders.

Phase Three: Leadership Differentiated. In Phase 3: Leadership Differentiated students solidified their views of leadership, moved further along the path to collaborative leadership, and understood how leaders could be in both positional and nonpositional roles. Enhanced self-confidence and exploration of who they wanted to be led these students to fully internalize self as leader into their identities. They also recognized their responsibility to lead by example and serve as role models for others, understanding leadership as more of a process than a position (Komives, Longerbeam, Owen, Mainella, \& Osteen, 2006).

Expanding views of leadership. Early in Phase 3, students viewed leadership related to one's passion as shared by Wendy, who referred to "finding your passion and just going for it." Leaders were individuals who could gather others around an issue and motivate their peers toward the accomplishment of a goal. The students also recognized that leaders had to relinquish control, allowing others to take responsibility even if doing so meant tasks were not completed exactly as they would have done them, acknowledging others had approaches to contribute to goal accomplishment. Christine stated, "If the end goal was a program that was good that people came to, it didn't really matter how we got there."

As students progressed in Phase 3, their views of leadership shifted toward the notion that anyone could be a leader as illustrated by the following data excerpts: "Being a leader can be anything. ... A random student could be a leader" (Wendy); "Anybody has the 
potential to be a leader" (Bridget). They realized that leadership was not specifically about holding a position or having a label or title but that leaders could come from anywhere and that anyone could lead. As the students' views shifted, they became aware that they no longer needed to be the kind of leaders others wanted them to be but that they could be who they were and that was sufficient. This new awareness implied a conscious incorporation of being a leader into the students' identities.

Changing views of self as leader. Students in Phase 3 came to understand how they had the ability to actively influence the growth of other students by delegating responsibility and empowering others to make decisions. Students perceived their role in terms of helping others find themselves and become leaders. Faith shared her experiences with "making sure that [student leaders] feel empowered to make decisions and empowered to tell people when they're making their jobs hard." Helping others become leaders also meant providing opportunities like the ones they had been given. These students served as sounding boards for their peers, now playing the role that others had for them.

As skills and abilities were being further developed, these students examined who they were and who they wanted to be as leaders. The students at Phase 3 realized that they needed to adapt to the needs of their peers as illustrated by the following data excerpts: "You have to tailor what you're doing to the specific person and what their needs are" (Catherine); "Because each group that you lead or each position you're put into is going to be different, ... you have to be able to kind of morph into different scenarios and situations" (Melissa). Meeting others where they were and openness to others' ideas were essential as was knowing oneself. These students understood that being a leader was not always about being the center of attention. They also became more comfortable with their views of right and wrong and their ability to stand up for an issue that needed to be addressed even when facing conflict with others.

"Aha" moment. A major aspect of the students' development in Phase 3: Leadership Differentiated was the experience of having an "aha" moment in relation to their leadership identity. For Cassie, this moment came when she recognized that she truly was a leader. She stated:

I definitely see my transformation as a leader and now realizing that I didn't give myself enough credit before.... [I] think I can actually now see myself as a leader ... that I can be quiet, introverted, and lead by example, and that can be viewed as leadership, not as someone that leads meetings or has an important position or has more of an aggressive, direct leadership style.

The impact of these "aha" moments in conjunction with their expanding understanding that being a leader was not directly tied to being in a position of authority were critical to the students' true internalization of self-as-leader into their identity.

Perception of female leaders. A shift occurred in Phase 3 as students began to more fully connect their identities as females to their identities as 
leaders, different from earlier phases. A developing consciousness of what being a female leader meant in general and for themselves, lead to a realization that the students had a voice and that they could express their opinions without fear. Grace said, "If there's a problem, it needs to be said, and people need to know about it so something can be done." The two aspects of their identity - gender and leader - intersected, and students explored what the connection meant for the way they led.

In Phase 3 students provided specific examples of times they had been pushed aside or ignored as female leaders. Holly shared her experience on the primarily-male executive board of an organization associated with her male-dominated major. She said, "So that's probably one of the biggest challenges is trying to put something out there and then it being shut down. With ideas that are put out and kind of pushed aside." She had to learn how to navigate being ignored or having her ideas downplayed due to her gender in order to be successful at achieving her goals for the organization. These students applied their personal experiences when pushed aside to determine ways to have their voices heard.

Students in Phase 3 also developed a belief in women's abilities as leaders and incorporated that belief into their own identities. These students looked to female role models as examples of what they could accomplish and felt comfortable with their own choices as a result of their newfound confidence. Hoping to disprove societal stereotypes of female leaders, Penny stated, "I feel like I always want to crush that stereotype of a woman can't be a leader."

Confidence in who they were allowed students in Phase 3 to incorporate the role of leader into their identities. For some students early in this phase, doing so meant continuing to push themselves outside their comfort zones. By the end of this phase, most of the students had become comfortable with who they were as individuals and as women. The students gained a solid knowledge of their own preferences and held themselves to high standards but also gave themselves space to make and learn from mistakes as in Bridget's comment about "taking risks and taking challenges and sometimes even failing and just picking yourself back up." They realized that who they were continued to evolve and would continue to do so for the rest of their lives.

Transition from Phase 3 to Phase 4. As these students moved into and through Phase 3: Leadership Differentiated, belief in themselves as leaders was strengthened. They saw leadership as externally focused on helping their peers develop and seeing their organizations succeed rather than being internally focused on aspects of command and control. The confidence that students developed during Phase 3 encouraged them to believe that they could address issues and make a positive difference that led some of them to transition into Phase 4: Generativity. In addition, students at the end of Phase 3 embraced their emerging identity as females and merged being female and being a leader into one, which developed further for students as they moved into Phase 4.

Phase 4: Generativity. In Phase 4: Generativity self-identity as a leader had been integrated and the students reflected the use of newly developed confidence and voice to do the right thing. This phase also involved an understanding of the responsibility to develop other 
students as leaders, which was consistent with the way Komives et al. (2005) defined generativity, that is, commitment to larger purposes and acceptance of the responsibility to develop others. In addition, Phase 4 was characterized by a shift from one's own leadership identity development to a desire to promote social change. Few students in this study, however, achieved Phase 4 in their leadership identity development process.

The students in Phase 4, as they developed self-confidence, reflected on the larger community and societal needs and considered their roles in addressing said needs. The first aspect of leader identity in Phase 4 was a desire to mentor others, particularly other female student leaders. Mentoring meant stepping back from opportunities to allow others the chance to grow. These students also recognized that they had built upon the foundation that past leaders had laid for them and wanted to provide that same foundation for others. Grace said:

There's a network of women that have already done it. . . They've already fought for students of color to do this and that. They've done a lot of legwork for us to be in positions that we are in.... So for them to do that legwork inspires me to make the same changes for the next generation.

Samantha perceived her leadership ability as a way to encourage other African American females to embrace their gender and racial identities and be proud of who they were and used every opportunity given to her to instill confidence in young women as she illustrated with this example about a song she wrote:

And I wrote it to inspire all ages of African American women to help them-it's just an empowerment song to basically help them realize that you know what? You're beautiful. You're worth it, and you can accomplish anything you want in life. Don't let anyone tell you that you can't.

The students at Phase 4 identified ways to be leaders and use their voices to challenge stereotypes and mentor other females toward the achievement of their dreams.

Social change was the second tenet associated with the leadership identity of students in Phase 4. They learned that making change happen was a process and that it was difficult and time-consuming, but if it was the right thing to do, it should be done. They had come to learn that they needed no acknowledgement from their peers about their leadership involvement to assure themselves that they were leaders. These students also believed that they could not let roadblocks deter them from working toward positive change. In Phase 4 students saw their roles as leaders (positional or not) in terms of doing what was right and taking a stand when right was challenged. These students had internalized an aspect of activism and inserted it into their leadership identities particularly around issues of gender and race, expressing a desire to break down stereotypes and to help women realize the impact of gender on their life experiences.

Students who had transitioned to Phase 4 worked to bring about change and showed their abilities to be change agents as illustrated by the following data excerpts: "I am not afraid to speak my mind and have a voice" (Samantha); "There's so many male characters, and I find a problem as an actor is that there are never good enough female roles that are actually round and 
dynamic. And not just the girlfriend, the housewife. ... I want to change that" (Rhonda). A key understanding of Phase 4 was the realization that change could occur on both micro and macro levels and that a leader did not have to make change happen in the larger society to be effective. Change was sometimes best served at the local level in an organization with the hope and desire that this small change would ripple out to broader and broader communities. For some students this was an important distinction because they could be intimidated by the idea of "large" change and lack belief in their ability to influence those kinds of societal shifts. The students who reached Phase 4 had been able to explore aspects of who they were as females and who they were as leaders and bring those two identities together, making them stronger and increasing their confidence in their abilities.

\section{Discussion}

College Student Leadership Development. Shertzer and Schuh (2004) stated that the ways students defined leadership may play a significant role in their perceptions of themselves as leaders. Constraints to leadership development described by Shertzer and Schuh were exhibited by participants in this study through their lack of belief in self, particularly in early phases of the model. For many students in Phase 1: Awareness and Exploration and Phase 2: Leader Identified, leadership was defined as positional or characterized by certain qualities or traits that the students did not perceive themselves possessing. In Phase 2, a number of students exhibited a lack of both confidence and belief in their capability to be a leader. Students expressed this lack of self-confidence even when in leadership roles or exhibiting leadership abilities. Although others may have seen the students' abilities, the students did not.

Given that trait theory posits that individuals possess an innate or inborn set of characteristics or qualities that make them leaders (Northouse, 2010), it is not surprising that the students in this study illustrated the impact of traits on their identities as leaders, particularly in Phases 1 and 2. This view of leadership traits is why so many students in Phase 1 did not perceive themselves as leaders as exemplified by Cassie describing herself as "just a member" and not a leader because she believed she lacked the traits identified as necessary for a leader.

College women and leadership development. In research focused specifically on female college students, Boatwright and Egidio (2003) found that women do not frequently express aspirations for leadership. This view was consistent with opinions expressed by several students in this study, who did not want to be leaders or did not see themselves as leaders. Students particularly in Phase 1: Awareness and Exploration and Phase 2: Leader Identified reflected Boatwright and Egidio's findings that students who held traditionally feminine gender stereotypes, such as being quiet, were likely to exhibit less aspiration to lead. Students in later leadership identity development phases accepted leadership as a part of their identities and sought out opportunities to serve in leadership roles. This developmental shift based on students' experiences provided insight that female students could develop stronger aspirations for leadership.

Students in early leadership identity development phases did not see how their views were based on socially constructed views of gender and appeared to accept the way they perceived their situations as normal. Students in this study believed their leadership experiences 
had been primarily positive, with few exceptions. Even when identifying a negative experience, the students attributed it more to personality or position than to the role gender played in the situation as in the case of Leigh, who deferred during a crisis situation to a male enrolled in the police academy even though she had the same knowledge and ability to take charge. This raises questions about how leadership educators address gender in their programming and what they are or are not doing to provide opportunities for students to explore the role gender plays in their lives.

Findings from a number of studies on college women and leadership indicated the value female student leaders placed on collaboration, positivity, support for others, and the importance of helping to being a leader (Haber, 2011; Haber-Curran, 2013; Romano, 1996; Whitt, 1994). Although limited leadership research has been conducted on female college students, I found many consistencies in my findings and existing research. More research needs to be conducted in this area, but the connections are encouraging.

\section{Implications and Conclusion}

The lack of connection at early phases of leadership identity development to what leadership meant to students provides an opportunity for leadership educators to examine the connection with their students, helping them to define leadership and to consider how their involvement and activities connect with their definition. This type of exploration could prompt students to move more quickly through Phase 1 into Phase 2, where they see themselves as leaders and to apply what they learned from their past experiences. Leadership educators should increase their awareness of emerging, contemporary leadership perspectives and leadership identity development models and consider how to incorporate the understanding of students' developmental processes, including gender identity, into their programs.

Gender Identity Development. Participants in this study showed limited awareness of their own gender identity. Consistent with Boatwright and Egidio's (2003) findings, the participants did not often express a desire to be a leader, or more specifically a female leader. Understanding that women are still perceived differently than men as leaders, exploration of gender identity as well as socially constructed views of gender should be incorporated into leadership development programs. Students in my study were involved, engaged with their campus communities, and made progress in developing their leadership identities; but with a few exceptions they were not challenged to explore their gender identity and the manner in which the social construction of gender impacted their leadership identity development. Colleges and universities do a disservice to their female students by leaving them unprepared for the experiences and challenges they may face as females in the workplace, and one way this exploration of identity and development of abilities to address challenges can be accomplished is through leadership education initiatives. Programs should provide activities that give students a sense of discomfort and dissonance in order to encourage their exploration of other aspects of their identity and what that means for them as leaders. This could be done through the use of clips from television or movies that illustrate females in a variety of leadership roles. Stories of recently graduated female leaders should be heard by students participating in leadership education programs to provide a frame of reference and relevant experiences from women who have recently been where they are. Female voices should also be heard in the readings and other 
media used in leadership education programs to provide a balanced perspective on leadership, and contemporary models of leadership like relational leadership should be explored.

The incorporation of gender identity exploration into leadership programs yields an implication for leadership educators themselves, who should explore their own assumptions about leadership and about gender. Educators bring assumptions and acceptance of socially constructed gender roles to the work they do, often unconsciously. They need to challenge themselves about what they believe and how those beliefs are reflected in the programs they offer. Leadership educators must also be willing to confront sexism when it occurs in their programs, addressing sexist comments and providing brave spaces for students to explore what they know about gender identity and their acceptance of socially constructed views and to develop skills to challenge those views in themselves first and then in the larger community. Although this process of self-exploration and learning may present challenges to educators, it is important for leadership educators to make these changes in their programs in order to contribute to students' leadership identity development.

Programming Specifically for Female Students. The students in this study indicated that their early views of leadership were shaped by the way society assigns gender roles and perceives female leaders. Boatwright and Egidio (2003) found that female students who held feminine views of leadership styles had lower leadership aspirations. The students in this study came into their college experience holding very traditional view of leadership traits and skills commonly identified as masculine in the leadership scholarship. Until students moved into Phase 3: Leadership Differentiated, they made little connection to their identity as females and even less connection to what that meant for them in terms of how they lead or were perceived as leaders by their peers. The comments and experiences shared were consistent with Haber (2011) and Haber-Curran (2013), particularly related to Haber-Curran's (2013) findings on the importance of relationships and how students were perceived by their peers.

A majority of leadership development programs are open to any and all students, resulting in difficulty addressing the specific needs of certain student populations (Arminio et al., 2000; Dugan, 2011). One-size-fits-all programs do not often address the multiple identities students bring to their leadership roles and instead focus specifically on traits and characteristics needed to be successful leaders. The findings from this study indicate a strong need for the development of leadership education initiatives that focus specifically on women. Providing separate opportunities for female students to explore what leadership means to them and how they come to identify as a leader with a focus on supporting and affirming women's identity, aspirations, and accomplishments (Sagaria, 1988) is invaluable. Providing an environment of only females avoids both the need to impress the males in the room or to defer to them. Connecting female students with strong female role models should be another aspect of femaleonly leadership development programs (Astin \& Leland, 1991) as well as opportunities for students to network with and learn from women in leadership roles in a range of organizations (Haber-Curran, 2013). Hosting roundtable discussions for female student leaders is one approach to consider. Finally, leadership educators must create opportunities for female students to develop skills and to be leaders as a way to level the playing field for women, both during their college years and after graduation. 
Merely educating female students about various approaches to leadership and challenging the stereotypes of women as leaders is, however, insufficient (Eagly \& Carli, 2007; Haber, 2011; Kezar \& Moriarty, 2000). Male students need this education as well. Students of both genders must be educated about how society has defined who leaders are, how leaders should behave, and the benefits to having more female leaders in order to bring about changes in societal views. Discussions about gendered views of leadership in programs should be held as a way to initiate this educational process. Leadership educators cannot focus on just one side of the equation and imagine that change will happen: They must educate all students.

\section{Conclusion}

Leadership identity development is a complex, evolving process; female students appear to experience some aspects of this process differently. Gaining an understanding of this developmental process can benefit leadership educators in the design of developmentally appropriate initiatives. Understanding how students develop a leadership identity could inform the design of leadership development programs and create opportunities for new initiatives aimed at achieving institutional missions of developing students into leaders. Additional research is needed to understand more fully how leadership identity development occurs including in relation to the intersection of multiple identities (i.e. gender, race, ability). Ultimately, higher education institutions have a responsibility to prepare female students for the realities of being leaders in society and for addressing social views of gender and leaders with all students in educational realms.

\section{References}

Arminio, J. L., Carter, S., Jones, S. E., Kruger, K., Lucas, N., Washington, J., Young, N., ... Scott, A. (2000). Leadership experiences of students of color. NASPA Journal,37, 496-510.

Astin, H. S., \& Leland, C. (1991). Women of influence, women of vision: A cross-generational study of leaders and social change. San Francisco, CA: Jossey-Bass.

Boatwright, K. J., \& Egidio, R. K. (2003). Psychological predictors of college women's leadership aspirations. Journal of College Student Development, 44, 653-669. Bureau of Labor Statistics. (2013). Labor force statistics from the current population survey. Retrieved from http://www.bls.gov/cps/demographics.htm\#women

Charmaz, K. (2014). Constructing grounded theory (2 $2^{\text {nd }}$ ed.). Los Angeles, CA: Sage.

Charmaz, K. (2006). Constructing grounded theory: A practical guide through qualitative analysis. Los Angeles, CA: Sage.

Cress, C. M., Astin, H. S., Zimmerman-Oster, K., \& Burkhardt, C. J. (2001). Developmental outcomes of college students' involvement in leadership activities. Journal of College Student Development, 42(1), 15-27. 
Day, D. V., \& Harrison, M. M. (2007). A multilevel, identity-based approach to leadership development. Human Resource Management Review, 17, 360-373.

DiPaolo, D. G. (2008). Echoes of leadership education: Reflections on failure, forgetting, and our future. Journal of Leadership Education, 7(1), 77-91.

Dugan, J. P. (2011, Winter). Students' involvement in group experiences and connections to leadership development. New Directions for Institutional Research, 17-32.

Dugan, J. P., Komives, S. R., \& Segar, T. C. (2008). College students capacity for socially responsible leadership: Understanding norms and influences of race, gender, and sexual orientation. NASPA Journal, 45(4), 475-500.

Eagly, A. H., \& Carli, L. L. (2007). Through the labyrinth: The truth about how women become leaders. Boston, MA: Harvard Business School Press.

Eich, D. (2008). A grounded theory of high-quality leadership programs: Perspectives from student leadership development programs in higher education. Journal of Leadership \& Organizational Studies, 15, 176-187. doi: 10.1177/ 1548051808324099

Gage, A. J., Mumma, S., \& Fritz, S. (2004). Exploring the Bermuda Triangle: Review of gender, societal, team and individual leadership theories. The Journal of Leadership Education, 3(2), 35-51.

Gonda, W. V. (2007). The development of leadership identity: A study of young, professional women (Unpublished master's thesis). Mercyhurst College, Erie, PA.

Haber, P. (2011). Iron sharpens iron: Exploring the experiences of female college student leaders. Advancing Women in Leadership, 3(1), 86-101.

Haber-Curran, P. (2013). The delicate balancing act: Challenges and successes facing college student women in formal leadership roles. NASPA Journal About Women in Higher Education, 6(1), 71-98. doi: 10.1515/njawhe-2013-0005

Harper, S. R., \& Quaye, S. J. (2007, March/April). Student organizations as venues for Black identity expression and development among African American male student leaders. Journal of College Student Development, 48, 127-144.

Helgesen, S. (1990). The female advantage: Women's ways of leadership. New York, NY: Doubleday Currency.

Hoyt, M. A., \& Kennedy, C. L. (2008). Leadership and adolescent girls: A qualitative study of leadership development. American Journal of Community Psychology, 43, 203219. doi: 10:1007/s10464-008-9206-8 
Kezar, A., \& Moriarty, D. (2000, January/February). Expanding our understanding of student leadership development: A study exploring gender and ethnic identity.

Komives, S. R., \& Johnson, M. (2009). The role of high school experience in college student leadership development. Educational Considerations, 37(1), 30-39.

Komives, S. R., Longerbeam, S. D., Owen, J. E., Mainella, F. C., \& Osteen, L. (2006). A leadership identity development model: Applications from a grounded theory. Journal of College Student Development, 47(4), 401-418.

Komives, S. R., Lucas, N., \& McMahon, T. R. (2013). Exploring leadership: For college students who want to make a difference ( $3^{\text {rd }}$ ed.). San Francisco, CA: Jossey-Bass.

Komives, S. R., Owen, J. E., Longerbeam, S. D., Mainella, F. C., \& Osteen, L. (2005). Developing a leadership identity: A grounded theory. Journal of College Student Development, 46(6), 593-611.

Komives, S. R., Wagner, W., \& Associates. (2009). Leadership for a better world: Understanding the social change model of leadership. San Francisco, CA: Jossey-Bass.

Kouzes, J. M., \& Posner, B. Z. (2008). The student leadership challenge: Five practices for exemplary leaders. San Francisco, CA: Jossey-Bass.

Lawhead, J. (2013). Leadership identity development in Greek life organizations: Lessons learned. Unpublished manuscript.

Lord, R. G., \& Hall, R. J. (2005). Identity, deep structure and the development of leadership skill. The Leadership Quarterly, 16, 591-615.

Northouse, P. G. (2010). Leadership: Theory and practice (5 $5^{\text {th }}$ ed.). Los Angeles, CA: Sage.

Pittinsky, T. L., Bacon, L. M., \& Welle, B. (2007). The great woman theory of leadership? Perils of positive stereotypes and precarious pedestals. In B. Kellerman \& D. L. Rhode (Eds.), Women and leadership: The state of play and strategies for change (pp. 93-117). San Francisco, CA: Jossey-Bass.

Posner, B. Z. (2009, September/October). A longitudinal study examining changes in students' behavior. Journal of College Student Development, 50, 551-563.

Rhode, D. L., \& Kellerman, B. (2007). Women and leadership: The state of play. In B. Kellerman \& D. L. Rhode (Eds.), Women and leadership: The state of play and strategies for change (pp. 1-35). San Francisco, CA: Jossey-Bass.

Romano, C. R. (1996). A qualitative study of women student leaders. Journal of College Student Development, 37(6), 676-683. 
Roy, R. E., Weibust, K. S., \& Miller, C. T. (2009). If she's a feminist it must not be discrimination: The power of the feminist label on observers' attributions about a sexist event. Sex Roles, 60, 422-431.

Sagaria, M. A. D. (1988). The case for empowering women as leaders in higher education. New Directions for Student Services, 44, 5-11.

Shankman, M. L., \& Allen, S. J. (2008). Emotionally intelligent leadership: A guide for college students. San Francisco, CA: Jossey-Bass.

Shehane, M. R., Sturtevant, K. A., Moore, L. L., \& Dooley, K. E. (2012). First-year student perceptions related to leadership awareness and influences. Journal of Leadership Education, 11 (1), 140-156.

Shertzer, J. E., \& Schuh, J. H. (2004). College student perceptions of leadership: Empowering and constraining beliefs. NASPA Journal, 42, 111-131.

Thompson, M. D. (2006, May/June). Student leadership process development: An assessment of contributing college resources. Journal of College Student Development, 47, 343-350.

Valian, V. (1998). Why so slow? The advancement of women. Cambridge, MA: Massachusetts Institute of Technology Press.

Whitt, E. J. (1994). "I can be anything!": Student leadership in three women's colleges. Journal of College Student Development, 35, 198-207.

\section{Author Biography}

Brenda L. McKenzie currently serves as a Senior Lecturer in Higher Education Administration at Vanderbilt University. Her research interests focus on college student leadership education and women and leadership. She has over 20 years of experience in the field of student affairs. 